\title{
Sciendo
}

DOI: $10.2478 /$ lpts-2020-0006

\section{DATA REDUCTION AND IMAGING OF GRAVITATIONAL LENS SYSTEM CLASS B0631+519}

\author{
K. Prūsis*, A. Nikolajevs \\ Engineering Research Institute \\ "Ventspils International Radio Astronomy Center", \\ Ventspils University of Applied Sciences, \\ 101 Inzenieru Str., Ventspils, LV-3601, LATVIA \\ *e-mail: kaspars.prusis@venta.lv
}

The present paper describes reduction procedures and imaging of radio astronomical data from the gravitational lens system CLASS B0631+519 acquired by e-MERLIN interferometer. The source has been previously imaged with VLA, MERLIN and the VLBA interferometers. Data reduction and polarisation calibration procedures will provide data on Faraday effects such as Faraday rotation and depolarization between lensed images that in turn carry information on large and small-scale magnetic fields in the lensing galaxy.

Reduction of data and imaging of the radio astronomical source have been achieved using Astronomical Image Processing System (AIPS) in conjunction with automatic data reduction pipelines that performed specific data processing steps. As a result, the sky map for the gravitational lens system has been successfully acquired and accuracy comparing the generated map to sky maps of the source produced by different authors has been confirmed.

Keywords: AIPS, gravitational lensing, Parseltongue, SERPent

\section{INTRODUCTION}

Strong gravitational lensing is a phenomenon when a background source obscured by a massive galaxy or a cluster of galaxies is multiply imaged and visible in the field of site besides the intervening or lensing galaxy. It is caused by the gravitational field of the intervening galaxy that effectively bends the ray-path emitted by background source [1]. A visual representation of basic gravitational lensing is shown in Fig. 1. 


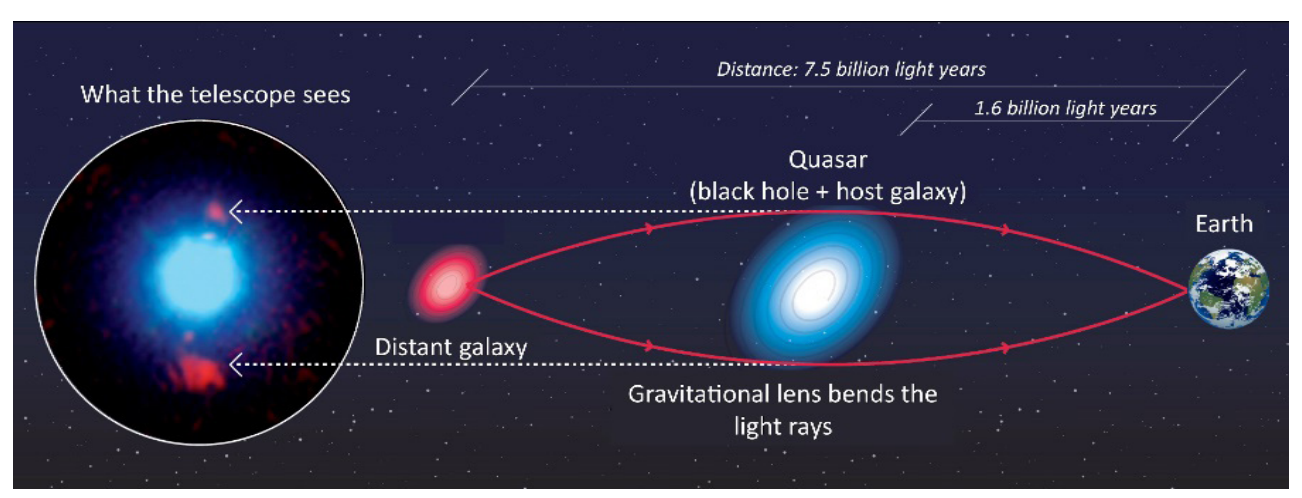

Fig. 1. Image describing principles of gravitational lensing. The image itself is of the quasar SDSS J0013+1523 (blue), bracketed by the lensed images of the background galaxy (red), obtained with the W. M. Keck Observatory's 10 m telescope and Adaptive Optics. From "Caltech / EPFL / WMKO” by F. Courbin, S. G. Djorgovski, G. Meylan, et al., 2010, http://www.astro.caltech.edu/ george/qsolens/ lensillustration.jpg.

CLASS B0631+519 (Fig. 2) has one of the richest lensed image structures known and is thus an ideal system to probe mass properties of the lensing galaxy, including Faraday rotation and depolarization between lensed images to determine large and small-scale magnetic fields in the lensing galaxy. Unlike the standard Faraday rotation measure grid technique, the lensing approach can deliver Faraday rotation and Faraday dispersion produced by a distant intervening galaxy free of contamination from the background source and the Milky Way. [2]

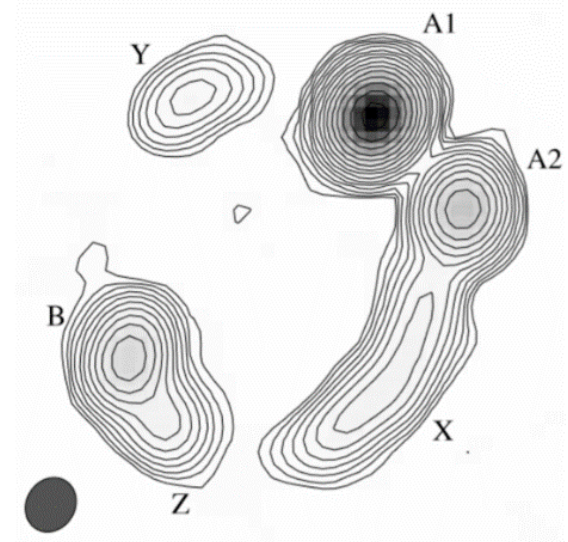

Fig. 2. Radio map of the $1.7 \mathrm{GHz}$ MERLIN observations taken on 1 March 2003. The data were naturally weighted. The synthesized beam is sized $186 \times 161$ mas at P.A. $-31.7 \circ$. Contours are plotted at factors of $(-3,3,4.5,6.75,10.1,15.2,22.8,34.2,51.3,76.9,115,173,259,389,584,876)$ times the RMS noise [1].

In order to obtain information on Faraday effects, extensive processing of raw correlated data must be performed to acquire the image of the galaxy and perform polarization calibration (see Fig. 3) [3]-[5].

A full process starting from signal detection and ending with the generation of an image of a radio astronomical source is shown in Fig. 3. The data processing steps covered in green have been performed by the authors and are described in the paper. 


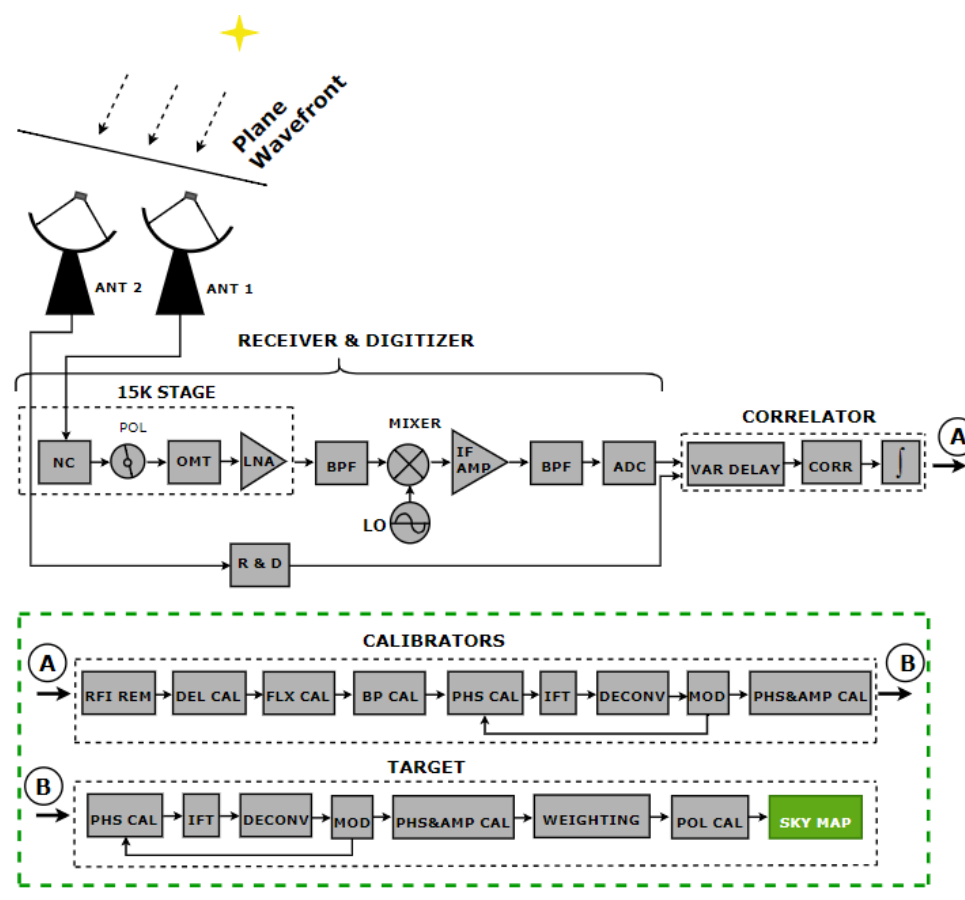

Fig. 3. Diagram of the approximate hardware and software needed to obtain an image of an astronomical source from signals detected by radio telescopes.

The following parts of the paper provide a deeper explanation of specific procedures and tools needed to obtain sky maps of astronomical objects. The results of data processing for CLASS B063+519 data are also given.

\section{E-MERLIN DATA FORMAT}

CLASS B0631+519 was observed and correlated using e-MERLIN radio interferometer, consisting of 7 telescopes (21 baseline in total) [6] and operating in standard continuum mode:

- $\quad$ Data were split into 8 sub-bands (called IFs);

- $\quad$ Each sub-band was $64 \mathrm{MHz}$ wide ( 8 by $64 \mathrm{MHz}=512 \mathrm{MHz} / \mathrm{BW}$ ), divided into 512 spectral channels;

- Observed bandwidth was 1250-1750 MHz;

- Expected RMS noise for a $12 \mathrm{hr}$ on-source observation run: $6 \mu \mathrm{Jy} / \mathrm{beam}$, twice this value if Lovell telescope was not included [7].

After observation, the correlated data were exported to a FITS-IDI standard file format. For a given observing run, each FITS file contained a single source, with multiple sub-bands per FITS file if these sub-bands were spectrally identical. The FITS-IDI data were hosted at Jodrell Bank Observatory (JBO) close to the correlator on archive disks [7]. 
Usually, a number of sources including the target are observed as part of the run because multiple sources need to be observed to perform calibration procedures for radio telescopes. The observation consists of scans from:

1. The target source (in particular case B0631+519);

2. The phase calibrator $(\mathrm{PH}-\mathrm{Cal})-0631+531$;

3. An absolute flux calibrator (FX-Cal) - 3C286 (1331+305);

4. A bright point-source calibrator (PT-Cal) - OQ208 $(1407+286)$;

5. A zero-polarization calibrator (ZEROPOL-Cal) - 3C84 (0319+415);

6. An absolute position angle calibrator (ANGPOL-Cal) - 3C286 $(1331+305)$.

The 25-hour observation is mainly structured in $\sim 10$ minute cycles, where approximately 3 minute $\mathrm{PH}-\mathrm{Cal}$ scans are followed by $\sim 7$ minute scans on the target supplemented with an hour or 2 hour long observations for other calibrators.

\section{DATA PROCESSING}

Data processing was carried out according to the guidelines provided in e-MERLIN COOKBOOK [7]. To perform data processing, a partly automated software eMERLIN pipeline.py [8] was used. Scripted E-merlin RFI-mitigation Pipeline for interferometry (SERPent) [9] was also utilised. The aim of these pipelines is to reduce the data processing burden for scientists and to reduce time required for data processing. It is very useful because some data processing steps can take up to several weeks when done manually. The pipelines were run using Parseltongue - a Python scripting interface for AIPS [10].

In order to make sure that any data processing steps had been successful, data had to be manually viewed for each baseline (21), both circular polarisations (RR and LL) and for each source. It means that after each data processing step at least 108 manual data viewing procedures had to be performed meaning that even with partial automation provided, still a large amount of time had to be spent to assure data quality.

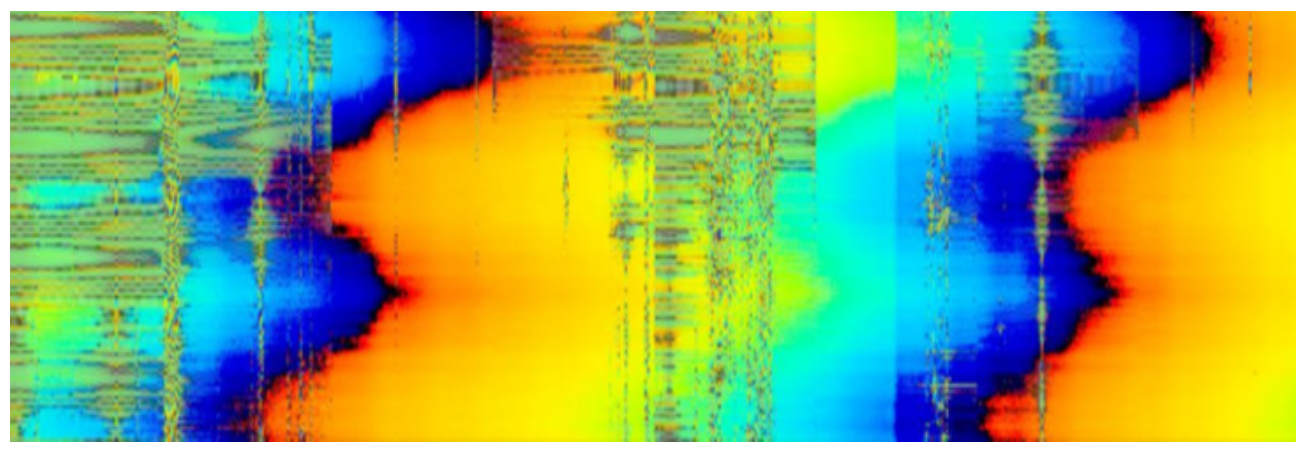

Fig. 4. An image acquired by AIPS task SPFLG for baseline Kn - Da showing data for PT-Cal. All 8 IFs are plotted. X-axis represents frequency, Y-axis represents signal frequency and colour represents the phase of the correlated signal. 
In Fig. 4, clear signs of high amplitude RFI can be seen as random phases at particular frequency channels. The amplitudes of uncalibrated data vary between a few $100 \mu \mathrm{Jy}$ to about 1 milliJy [7] but the amplitudes of RFI can reach up to hundreds of Jy.

This RFI is created mainly by transmitters used in communication systems and dominates over the true source signal and after averaging the data can ultimately destroy the coherency of data meaning that reconstruction of the source image is no longer possible. For this reason, to remove RFI, SERPent pipeline together with manual flagging was applied to all the sources, baselines, IFs and time ranges.

In Fig. 4, one can also see a gradual change in phase both in frequency and time. These are called delays or delay offsets. The phase of the interferometer is a function of the frequency multiplied by the delay, meaning delay offsets will show up as a phase slope across the frequency band. Furthermore, if the delay offset changes with time, so will the phase slope, resulting in an additional change in phase as a function of time known as the fringe rate [11], [12].

As stated in [11], there is a large number of ways in which the model used by the correlator can have errors, including errors in the source or antenna positions used, errors in the Earth model, errors in the clock epoch and rate at each antenna and errors in the atmospheric model. Correction of correlator model errors allows the data to be averaged in time and frequency, greatly reducing their volume.

Delay offsets for e-MERLIN data vary from couple up to few hundred nanoseconds and are generally larger on longer baselines. These delays can vary in time, either as gradual drifts, as fibres change temperature and length (note: 1 foot of length change corresponds to 1 nanosecond delay), or occasionally as sharp changes originating in the correlator [6]. If the delays and rates are very rapid after averaging, the coherency of the data may be destroyed. That is why delays have to be corrected as a function of time, which is performed by AIPS task FRING [7].

Fig. 5. Phase plot of correlated data for MK2-CM baseline after fringe fitting.

As can be seen in Fig. 5, delays and rates were successfully removed by AIPS task FRING (in contrast to Fig. 4 no phase slope in frequency and time is present). The delay correction must be performed on all calibrators and might need to be run multiple times to correct smaller delays for shorter baselines and larger delays that might be incurred on the longest baselines.

Finally, after carrying out calibration procedures for all calibrators the image generation procedures for the target source are presented. 
In order to perform imaging procedures, numerous sets of parameters must be set within AIPS. One of these is the cell size parameter that corresponds and should be set to the maximum resolution of an interferometer.

In general, the resolution or synthesized beam width of an interferometer is calculated as $\Omega=\lambda / \mathrm{D}$ where $D$ is the maximum separation between two antennas and $\lambda$ is the wavelength. Maximum distance expressed in wavelengths $D_{\lambda}$ can be easily found using AIPS task UVPLT and in this case $D_{\lambda} \approx 1.3 \cdot 10^{6}$. Knowing this parameter, a resolution of an interferometer can be expressed as $\Omega \approx 1 / D_{\lambda}$ and the resolution was calculated to be $\Omega=158.67$ milliarcseconds (mas).

Then 2D Inverse Fourier Transform (IFT) procedure was performed to transform data from Fourier domain to real plane. The first image that is acquired after 2D IFT procedure is called the "dirty image" because in this image the true source brightness is convolved with the PSF of the interferometer [13], [14]. The dirty image of the target source acquired after 2D IFT is shown in Fig. 6.

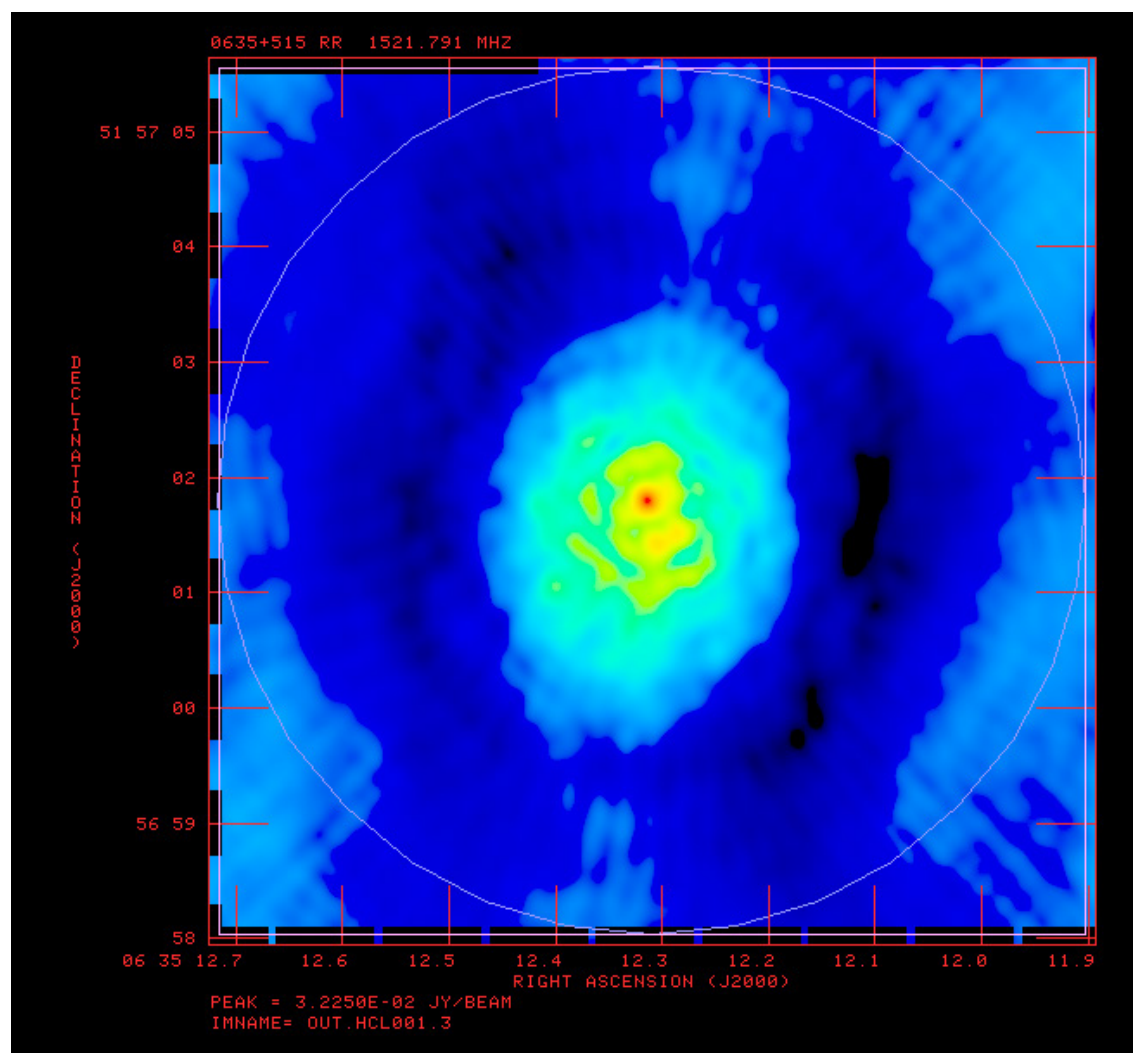

Fig. 6. The "dirty" image of the target source B0635+519 after the first 2D IFT cycle.

Looking at Fig. 6 only a partial source structure is visible compared to Fig. 2, which clearly indicates that true source brightness is convolved by the PSF of an interferometer.

In order to remove the effects of interferometer PSF, a deconvolution algorithm CLEAN implemented in AIPS was used [14]. 
During the execution of CLEAN algorithm, the coordinates of the maximum amplitude signal were searched in the sky map. When this position was found, a "component" (a spike at this position) was generated of some fraction (called the "gain") of the maximum in the image. This component was then convolved with the PSF of an interferometer and subtracted from the image. The subtracted components are also called "clean" components. This process was done for all the parts of the image and was iteratively repeated until the signal level of the map reached the minimum signal value set. After the process finished, an empty map was generated and collection of clean components was added to this map. They were convolved not with an instrumental PSF but with a more appropriate function, such as a Gaussian [13].

The sky map generated after the first CLEAN cycle is shown in Fig. 7.

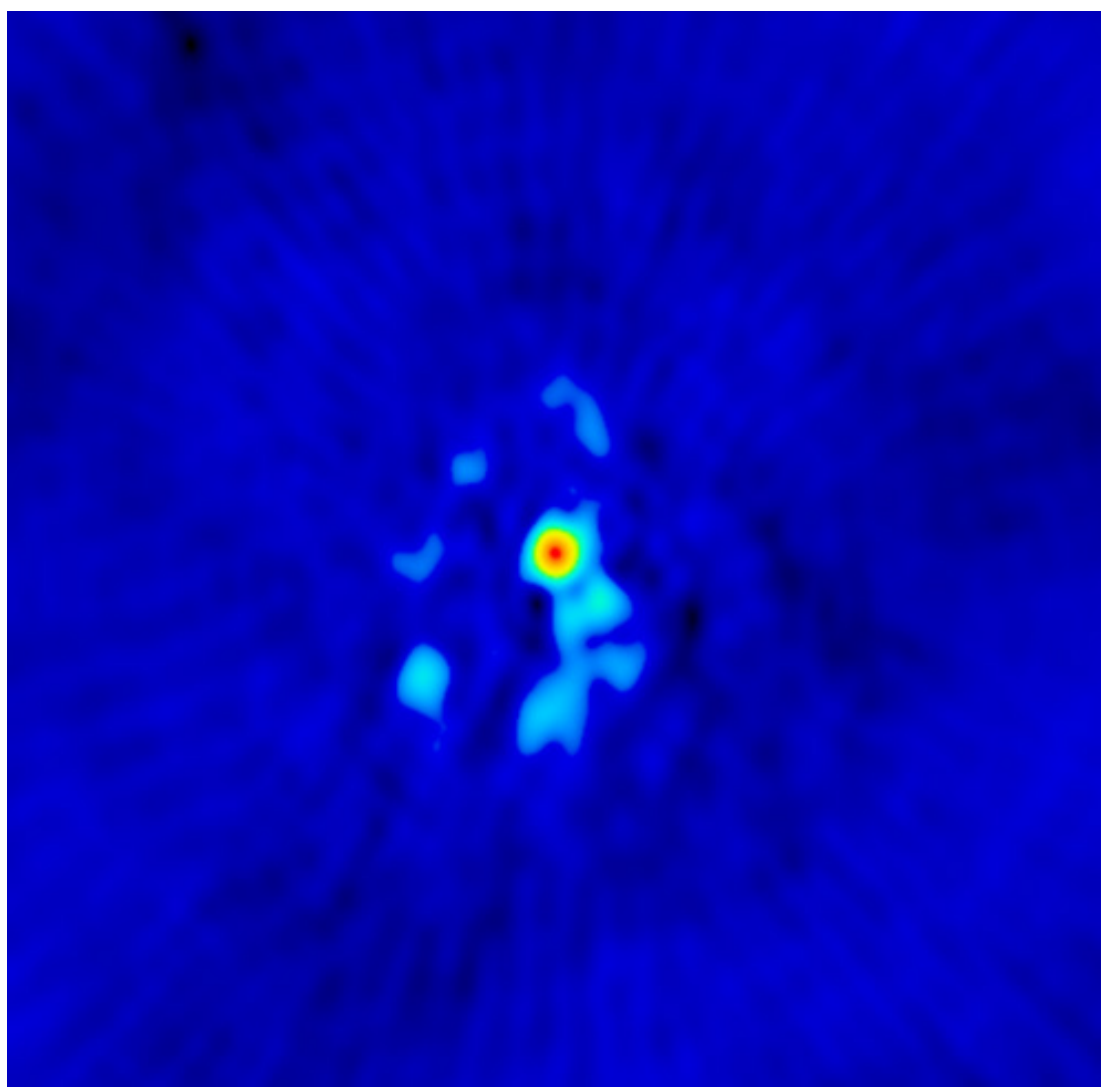

Fig. 7. The image of the target source B0635+519 after the first CLEAN deconvolution cycle.

In the sky map obtained for the target in Fig. 7, a clearer source structure was starting to emerge that better resembled the source structure in Fig. 2. However, further data processing cycles were needed to improve the image quality.

In order to acquire a precise sky map of the target, a self-calibration procedure was performed.

Self-calibration is a process that calculates telescope gains by comparing the observed data with a model of the sky. These gains are used to provide a corrected 
dataset, and hence a corrected image, and using this image the process can be repeated iteratively until convergence. The model is provided by the image produced from the data itself, hence, the "self" calibration - and in particular by the clean components (CC) table attached to the image. The procedure is carried out until data convergence is found [7], [15].

The target image obtained in Fig. 7 was used as a model for self-calibration cycles and this procedure was performed until data convergence and minimal noise level in the image were achieved. The final sky map of the target source after multiple phase and amplitude self-calibration cycles is shown in Fig. 8.

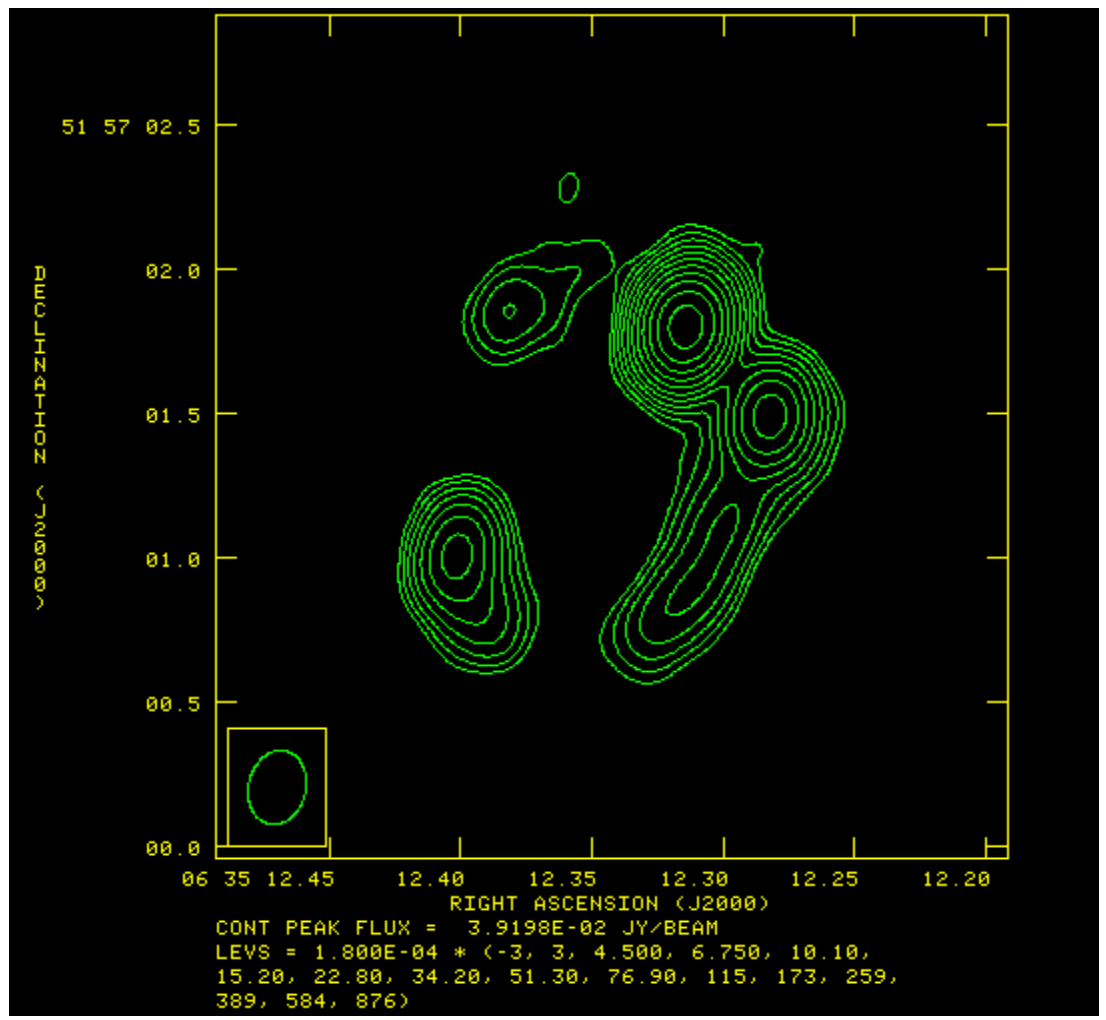

Fig. 8. A sky map of the target source B0635+519 after the 4th self-calibration cycle. The image is contour plotted using AIPS task KNTR. Contours are plotted at factors of $(-3,3,4.5,6.75,10.1,15.2$, $22.8,34.2,51.3,76.9,115,173,259,389)$ times the RMS noise $\left(-1.8 \mathrm{e}^{-04} \mathrm{Jy}\right)$.

\section{CONCLUSIONS}

Radio astronomical data reduction is an extensive, time-consuming and complex multi-step process involving various data processing tools and software. For example, when doing reduction for data acquired by e-MERLIN radio interferometer and performing diagnostic tests, information needs to be inspected for 21 baselines, where data are split into 2 circular polarisations, 8 sub-bands and multiple time periods, which resulted in the processing of more than 300 data chunks in one data reduction step. 
Nevertheless, numerous automated data processing pipelines and scripting interfaces, including e-MERLIN pipeline, SERPent and Parseltongue etc., have been introduced to remove data processing burden from scientists and to increase the speed of data reduction. While it greatly aids data reduction extensive manual processing, inspection still must be carried out leaving space for future improvements in data reduction automation.

Data reduction and calibration of e-MERLIN data for gravitational lens system CLASS B0631+519 performed by the authors have successfully been executed and the sky map of the object obtained. The RMS noise achieved in the image has been $180 \mu \mathrm{Jy} /$ beam and the total cleaned flux density has resulted in $66.8 \mathrm{mJy}$ which coincides with information available in NASA/IPAC Extragalactic Database (NED) [16] and results provided in [1].

As a whole, acquired knowledge in radio astronomical data processing and various data processing tools will allow VIRAC to participate in future collaborative scientific research concerning corresponding fields of science as well as to perform reduction of data acquired by VIRAC radio telescopes RT-32 and RT-16 not only in single station mode but also when interferometer network is formed, thus expanding VIRAC technological and scientific potential.

Further research must be conducted to perform polarization calibration in order to acquire information about Faraday rotation and depolarization between lensed images that in turn carry information on large and small-scale magnetic fields in the lensing galaxy.

\section{ACKNOWLEDGEMENTS}

The authors would like to thank Neal Jackson from Jodrell Bank Centre for Astrophysics (JBCA), Manchester, the UK, for his great help in providing theoretical basis in radio interferometry and giving assistance in data reduction process. The research has used data from the observations with the e-MERLIN that is a UK National Facility operated by the University of Manchester on behalf of Science and Technology Facilities Council (STFC).

Our recent work in this area has been supported by project No. 692257 BALTICS (Building on Advanced LOFAR Technology for Innovation, Collaboration, and Sustainability).

\section{REFERENCES}

1. York, T., Jackson, N., Browne, I.W.A., Koopmans, L.V.E., McKean, J.P., Norbury, M.A., ... \& Wilkinson, P.N. (2005). CLASS B0631 + 519 : Last of the Cosmic Lens All-Sky Survey Lenses. Monthly Notices of the Royal Astronomical Society, 361 (1), 259-271.

2. Mao, S.A., Carilli, C., Gaensler, B.M., Wucknitz, O., Keeton, C., Basu, A., ... \& Zweibel, E. (2017). Detection of Microgauss Coherent Magnetic Fields in a Galaxy Five Billion Years Ago. Nature Astronomy, 1 (9), 621-626.

3. Schwab, F.R., \& Cotton, W.D. (1983). Global Fringe Search Techniques for VLBI. The Astronomical Journal, 88, 688. 
4. Wrobel, J.M., \& Ulvestad, J.S. (1999). Very Long Baseline Array Observational Status Summary. NRAO.

5. Hogbom, W.N., Brouw, J.A. (1974). The Synthesis Radio Telescope at Westerbork. Principles of Operation, Performance and Data Reduction. Astron. Astrophys., 33, 289 301.

6. Garrington, S.T., Anderson, B., Baines, C., Battilana, J.A., Bentley, M.N., Brown D., ... \& Thomasson, P. (2004). e-MERLIN. Ground-based Telescopes, 5489, 332-344. Belles, P.E., Beswick, R., Argo, M., Jackson, N., Muxlow, T., \& Richards, A. (2015). e-MERLIN CookBook. JBCO.

7. Argo, M.K. (2015). The e-MERLIN Data Reduction Pipeline. J. Open Res. Softw., 3, 692257.

8. Peck, L.W., \& Fenech, D.M. (2013). SERPent: Automated Reduction and RFI-Mitigation Software for e-MERLIN. Astron. Comput., 2, 54-66.

9. Kettenis, M., van Langevelde, H. J., Reynolds, C., \& Cotton, B. (2006). ParselTongue: AIPS Talking Python. Astron. Data Anal. Softw. Syst. XV ASP Conf. Ser., 351, 497-500.

10. Cotton, W.D. (1995). Fringe-Fitting. Very Long Baseline Interferometry and the VLBA, $82,189-208$.

11. Morford, J.C. (2017). The e-MERLIN L-band Legacy Survey of Cygnus OB2. University College London.

12. Clark, B.G. (1980). An Efficient Implementation of the Algorithm 'CLEAN'. Astron. Astrophys., 89 (3), 377-378.

13. Cornwell, T.J. (2008). Multiscale CLEAN Deconvolution of Radio Synthesis Images. IEEE J. Sel. Top. Signal Process, 2, (5), 793-801.

14. Pearson, T.J., \& Readhead, A.C.S. (1984). Image Formation by Self-Calibration in Radio Astronomy. Annu. Rev. Astron. Astrophys., 22, 97-130.

15. NASA/IPAC Extragalactic Database. (2019). Available at https://ned.ipac.caltech. edu/cgi-bin/datasearch?search_type $=$ Photo_id\&objid $=8783263 \&$ objname $=$ CLASS B0631\%2B519\%3A\%5BYJB2005\%5D A1\&img_stamp=YES\&hconst=73.0\&omegam $=0.27 \&$ omegav $=0.73 \&$ corr_z $=1 \&$ of $=$ table $\#$ No 4 
K. Prūsis, A. Nikolajevs

Kopsavilkums

Rakstā tiek aprakstīts ar e-MERLIN interferometru iegūto gravitācijas lēcu sistēmas CLASS B0631+519 datu apstrādes un attēlveides process.

Iepriekšējie gravitācijas lēcu sistēmas novērojumi ir veikti, izmantojot VLA, MERLIN un VLBI interferometrus.

Datu apstrādes un polarizācijas kalibrācijas procedūras sniegs datus par Faradeja efektiem, piemēram, Faradeja rotāciju un depolarizāciju starp lēcu attēliem, kas savukārt satur informāciju par maza un liela mēroga magnētiskajiem laukiem lēcu galaktikā.

Datu apstrāde un debess ķermeņa attēlveide tika veikta, izmantojot astronomisko datu apstrādes sistēmu AIPS apvienojumā ar dažādām automātiskajām datu apstrādes programmām, kuras veica konkrētus datu apstrādes soḷus.

Rezultātā veiksmīgi tika iegūta gravitācijas lēcu sistēmas debess karte, un iegūtās kartes patiesums tika apstiprināts, salīdzinot to ar citu autoru iegūtajām gravitācijas lēcu sistēmas debess kartēm.

Iegūtās zināšanas radioastronomisko datu apstrādē un pieredze darbā ar dažādām astronomisko datu apstrādes programmām ḷaus VSRC nākotnē piedalīties kopīgos zinātniskajos pētîjumos, kā arī l̦aus veikt ar VSRC rīcībā esošo RT-32 un RT-16 radioteleskopu iegūto datu apstrādi ne tikai vienas antenas režīmā, bet arī interferometrijas režīmā, tādējādi paplašinot VSRC tehnologiisko un zinātnisko potenciālu.

Atslēgas vārdi: AIPS, gravitācijas lēcas, Parseltongue, SERPent 